\title{
Efficacy of different isolates of bacterial antagonist against Aloe vera soft rot pathogen (Erwinia chrysanthemi) under in vitro
}

\author{
M. SYAMALA \\ Department of Plant Pathology, Agricultural College and Research Institute (T.N.A.U.), COIMBATORE (T.N.) INDIA \\ (Email : ms_shayamala@ yahoo.co.in)
}

\begin{abstract}
Fifteen pathogenic isolates of Erwinia chrysanthemi, the soft rot of pathogen of Aloe vera were established from 15 different areas of Southern Tamil Nadu and their identity was confirmed by Microbial Type Culture Collection (MTCC) and Gene Bank, Chandigarh. Among the different Pseudomonas isolates tested in vitro, Pf 32 and Pf 45 was the most effective against the pathogen followed by Pf 4 and of the ten Bacillus subtilis tested in vitro, Bs5 was the most effective against $E$. chrysanthemi.
\end{abstract}

Key Words : Soft rot, Aloe vera, Pseudomonas isolates, Bacillus subtilis

View Point Article : Syamala, M. (2015). Efficacy of different isolates of bacterial antagonist against Aloe vera soft rot pathogen (Erwinia Chrysanthemi) under in vitro. Internat. J. agric. Sci., 11 (1): 125-129.

Article History : Received : 13.09.2014; Revised : 21.11.2014; Accepted : 07.12.2014 